\title{
Metode Weighted Product dalam Perancangan Sistem Pendukung Keputusan Penentuan Produk Unggulan Pada Industri Kecil Menengah
}

\author{
Aang Alim Murtopo \\ Email: Aang.alim@gmail.com \\ Program studi Teknik Informatika, STMIK YMI Tegal
}

\begin{abstract}
Abstraksi
Proses penentuan produk unggulan pada IKM yang dilakukan oleh Dinas Perindustrian dan Perdagangan dalam proses seleksi memerlukan waktu yang lama yang berkesan berbeliti belit. Melihat hal ini untuk mempercepat hasil pengambilan keputusan diperlukan satu sistem yang mendukung proses seleksi. Metode perancangan yang digunakan SDLC Metode ini memiliki tahap-tahap antara lain Analisis, Desain, Implementasi, Testing, Maintenance sedangkan metode perhitungan secara matematis menggunakan metode Weighted Product, metode ini memberikan nilai bobot dari setiap kriteria yang ada, proses penentuan dilakukan dengan menjumlahkan nilai dari setiap kriteria dan dipangkatkan, sehingga akan dihasilkan nilai dari setiap alternatif dan memberikan informasi produk kerajinan apa yang memiliki nilai yang sesuai dari proses penentuan produk kerajinan. Proses penentuan produk kerajinan dilakukan dengan 5 kriteria sebagai dasar penentuan, diantaranya Unit Kerja, Tenaga Kerja, Nilai Produksi, Nilai Investasi dan Nilai Kompetitif. Hasil dari perhitungan setiap penerapan metode dengan 3 alternatif IKM yaitu S1,S2 DAN S3 menunjukan S2 dengan nilai Vektor S = 0.0370 dan Nilai Vektor V=0.3382 Menjadi Ranking Tertinggi hal tersebut terimplementasi dalam sebuah sistem pendukung keputusan.
\end{abstract}

Kata kunci : Sistem Pendukung Keputusan, Weighted Product, Prioritas Pengembangan, Industri Kecil dan Menengah

\section{Pendahuluan.}

Globalisasi merupakan suatu fenomena yang mendorong perusahaan di tingkat mikro ekonomi untuk meningkatkan efisiensi agar mampu bersaing di tingkat lokal, nasional, maupun internasional[1]. Industri Kecil Menengah (IKM) adalah industri yang memiliki skala industri kecil dan menengah. Menurut Peraturan Kementerian Perindustrian No. 64 tahun 2016, industri kecil adalah industri yang memiliki karyawan maksimal 19 orang, memiliki nilai investasi kurang dari 1 miliar rupiah, tidak termasuk tanah dan bangunan tempat usaha. Sedangkan, yang dimaksud dengan industri menengah adalah industri yang memiliki tenaga kerja maksimal 19 orang dengan investasi minimal 1 miliar rupiah atau memiliki tenaga kerja minimal 20 orang dengan nilai investasi maksimal 15 miliar rupiah[2].

Sistem pendukung keputusan (SPK) adalah bagian dari sistem informasi berbasis komputer termasuk sistem berbasis pengetahuan atau manajemen pengetahuan yang dipakai untuk mendukung pengambilan keputusan dalam suatu organisasi atau perusahaan. Dapat juga dikatakan sebagai sistem komputer yang mengolah data menjadi informasi untuk mengambil keputusan dari masalah semi terstruktur yang spesifik[3]

Weighted Product (WP) merupakan salah satu metode yang digunakan untuk menyelesaikan masalah Multi Attribute Decision Making (MADM). Metode Weighted Product (WP) menggunakan perkalian untuk menghubungkan nilai atribut (kriteria), dimana nilai setiap atribut (kriteria) harus dipangkatkan dulu dengan bobot atribut (kriteria) yang bersangkutan[4].

Dinas Perindustrian dan Perdagangan Kabupaten Tegal dalam upaya untuk terus mengkaji potensi ekonomi dan sumber daya alam daerah di sektor industri kerajinan, berusaha untuk menentukan produk kerajinan dari jenis industri yang ada. Penentuan produk kerajinan ini sangat penting guna menentukan peluang ekspor bagi Industri Kecil dan Menengah. Kriteria dalam penentuan produk kerajinan diantaranya adalah Unit Kerja, Tenaga Kerja, Nilai Produksi, Nilai Investasi, Nilai Kompetitif

Dalam proses penentuan produk kerajinan merupakan hal yang sangat penting untuk menentukan kebijakan pemerintah daerah yang 
akan diambil, keakuratan data dalam proses seleksi sangat diperlukan supaya mendapatkan satu keputusan yang sesuai, hal yang dihadapi oleh Perindustrian dan Perdagangan Kabupaten Tegal dalam pengambilan keputusan membutuhkan waktu yang lama, proses seleksi dengan berbagai manca pertimbangan pertimbangan yang berbelit belit. Melihat hal hal tersebut maka diperlukan satu sistem yang dapat mengolah data sehingga didapat data yang akurat dan waktu yang cepat, maka dalam penelitian ini mencoba menerapkan Sistem Pendukung Keputusan Penentuan Produk Kerajinan. Metode yang digunakan dalam pengambilan keputusan penentuan produk adalah metode Weighted Product.

\section{Metode Penelitian}

Pengembangan Sistem Pendukung Keputusan di penelitian ini menggunakan metode Weighted Product (WP) dengan beberapa Kriteria. Antara lain Unit Kerja, Tenaga Kerja, Nilai Produksi, Nilai Investasi, dan Nilai Kompetitif.

\section{A. Konsep Perhitungan Metode Weighted Product}

Metode Weighted Product menggunakan teknik perkalian untuk menghubungkan rating atribut, dimana rating tiap atribut harus ditingkatkan terlebih dahulu dengan bobot atribut yang bersangkutan[5]. Langkah Langkah sebagai berikut:

1) Memberikan nilai bobot $W$

Pengambilan keputusan memberikan bobot, berdasarkan tingkat kepentingan kriteria masing-masing kriteria yang dibutuhkan.

2) Normalisasi bobot W

$$
W_{j}=\frac{W_{j}}{\sum W_{j}}
$$

Keterangan :

$\mathrm{S}$ : Preferensi alternatif dianalogikan sebagai vektor $\mathrm{S}$

$X_{i j}$ : Nilai variabel dari alternatif pada setiap atribut.

$$
\begin{array}{ll}
W_{j} & \text { : Nilai bobot kriteria } \\
\mathrm{n} & \text { : Banyaknya kriteria } \\
\mathrm{i} & \text { : Nilai alternatif } \\
\mathrm{j} & \text { : Nilai kriteria }
\end{array}
$$

3) Menghitung Vektor $S$

$$
\begin{gathered}
S_{i}=\prod \frac{n}{j}= \\
X_{i j} W_{j} \ldots \ldots \ldots .
\end{gathered}
$$

4) Menghitungkan Vektor Perangkingan

$$
\begin{aligned}
& V_{1}= \\
& \Pi \quad n j=1 x_{i j} w j \\
& \hline \Pi n j=\left(x_{j^{2}}{ }^{w j}\right)
\end{aligned}
$$

\section{B. Metode Perancangan Sistem}

Dalam perancangan sistem, dikembangkan dengan SDLC (System Development Life Cycle) metode waterfall untuk menghasilkan sistem yang sesuai dengan yang diharapkan. Metode ini memiliki tahap-tahap antara lain Analisis, Desain, Implementasi, Testing, Maintenance[6].

\section{Hasil dan Pembahasan}

Dalam hasil dan pembahasan penelitian ini diuraikan tentang bagaimana WP dapat menyelesaikan masalah yang ada, yaitu dengan menggunakan perkalian nilai kriteria terhadap bobot kriteria. Penjabaran hasil penelitian ditunjukkan dengan gambaran desain sistem serta perhitungan matematis dari WP dalam menentukan produk unggulan pada IKM.

\section{A. Pembahasan Implementasi Metode Weighted Product (WP).}

Kriteria dalam penelitian ini adalaah sebagai berikut:

$$
\begin{array}{ll}
\text { C1 } & =\text { Unit Kerja } \\
\text { C2 } & =\text { Tenaga Kerja } \\
\text { C3 } & =\text { Nilai Produksi } \\
\text { C4 } & =\text { Nilai Investasi } \\
\text { C5 } & =\text { Nilai Kompetitif }
\end{array}
$$

1) Pengambilan keputusan memberikan bobot, berdasarkan tingkat kepentingan kriteria masing- masing kriteria yang dibutuhkan $(\mathrm{C} 1=5, \mathrm{C} 2=4, \mathrm{C} 3=4, \mathrm{C} 4=3$ dan $\mathrm{C} 5=2$ ) 
Bentuk tabel kriteria dari setiap alternatif seleksi penentuan produk unggulan sebagai berikut:

Tabel 1. IKM yang akan diseleksi

\begin{tabular}{lccccc}
\hline \multirow{2}{*}{$\begin{array}{l}\text { Alternati } \\
\mathbf{f}\end{array}$} & \multicolumn{5}{c}{ Kreteria } \\
\cline { 2 - 6 } & 1 & $\mathrm{C}$ & $\mathrm{C} 3$ & $\mathrm{C} 4$ & $\mathrm{C}$ \\
\hline S1 & 80 & 75 & 2.500 .00 & 3.000 .00 & 90 \\
& & & 0 & 0 & \\
\hline S2 & 70 & 65 & 2.000 .00 & 2.500 .00 & 80 \\
& & & 0 & 0 & \\
\hline S3 & 75 & 80 & 3.000 .00 & 2.750 .00 & 85 \\
& & & 0 & 0 & \\
\hline
\end{tabular}

2) Normalisasi $\mathrm{W}$

Untuk nilai normalisasi $\mathrm{W}$ digunakan rumus persamaan 1 sebagai berikut
a. $\quad W_{1}=\frac{5}{5+4+4+3+2}=\frac{5}{18}=0,2778$
b. $W_{2}=\frac{4}{5+4+4+3+2}=\frac{4}{18}=0,2222$
c. $W_{3}=\frac{4}{5+4+4+3+2}=\frac{4}{18}=0,2222$
d. $W_{4}=\frac{3}{5+4+4+3+2}=\frac{3}{18}=0,1667$
e. $W_{5}=\frac{2}{5+4+4+3+2}=\frac{2}{18}=0,1111$

3) Menghitung Vektor $S$

Verktor S dihitung dengan menggunakan persamaan 2 sebagai berikut:

\begin{tabular}{|c|c|}
\hline S1 & $\left(80^{0,2778}\right) *\left(75^{0,2222}\right) *\left(2500000^{0,2222)}\right.$ \\
\hline$=$ & $*\left(3000000^{0,1667}\right) *\left(90^{0,1111}\right)=0.0368$ \\
\hline S2 & $\left(70^{0,2778}\right) *\left(65^{0,2222}\right) *(2000000$ \\
\hline$=$ & $0,2222) *\left(2500000^{0,1667}\right) *\left(80^{0,1111}\right)=$ \\
\hline & 0.0370 \\
\hline S3 & $* \quad\left(80^{-0,2222}\right)$ \\
\hline$=$ & $\begin{array}{l}\left(3000000^{0,2222}\right) *\left(2750000^{0,1667}\right) \\
\left(85^{0,1111}\right)=0,0356\end{array}$ \\
\hline
\end{tabular}

4) Menghitung Vektor $V$

Untuk mencari Vektor V perhitungannya menggunakan persamaan 3 dengan hasil sebagai berikut:

1. $V_{1}=\frac{0,0368}{0,0368+0,0370+0,0356}=0,3364$

2. $V_{2}=\frac{0,0370}{0,0368+0,0370+0,0356}=0,3382$

3. $V_{3}=\frac{0,0356}{0,0368+0,0370+0,0356}=0,3254$
Dari hasil perhitungan maka dapat diperoleh perinkingan dari tertinggi ke terendah tertuang dalam tabel 2 sebagai berikut::

Tabel 2. Hasil Perenkingan

\begin{tabular}{lccc}
\hline alternatif & S & VRenk & \\
\hline S2 & 0.0370 & 0.3382 & 1 \\
\hline S1 & 0.0368 & 0.3364 & 2 \\
\hline S3 & $\mathbf{0 . 0 3 5 6}$ & $\mathbf{0 . 3 2 5 4}$ & $\mathbf{3}$ \\
\hline
\end{tabular}

\section{B. Gambaran Desain Sistem}

1) Form Input identitas Industri Kecil dan menengan dan kriteria berserta nilai masingmasing kriteria yang akan di uji

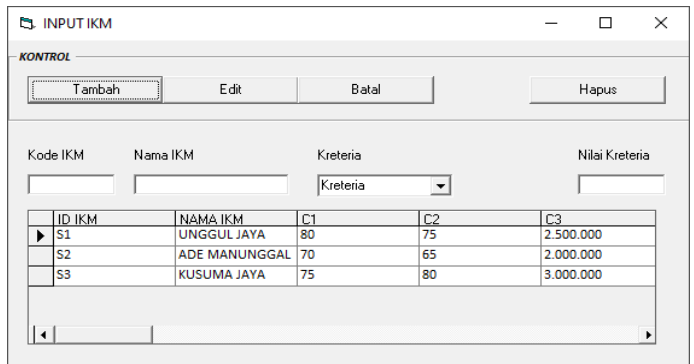

Gambar 1. Form Input Data yang akan di uji

2) Form Proses Normalisasi W menghitung Nilai Vektor S dan Vektor V terlihat pada gambar 2 sebagai berikut:

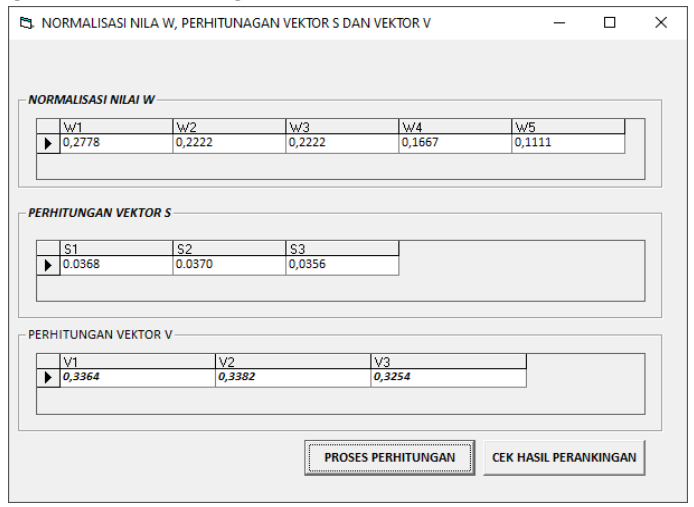

Gambar 2. Form Hasil Proses Perhitungan

3) Hasil perankingan dari kasus diatas tergambar pada gambar 3 berikut ini:

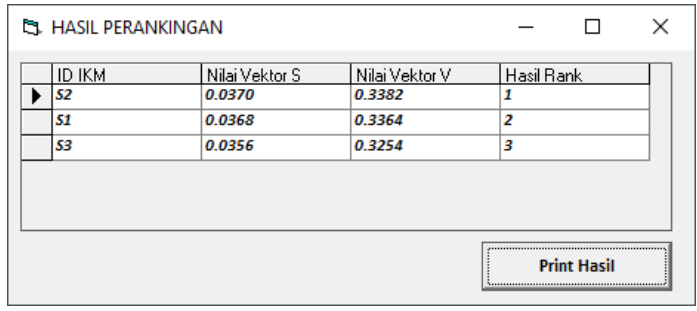

Gambar 3. Hasil Perankingan 


\section{Kesimpulan}

Berdasarkan dari pembahasan dalam penelitian ini, maka dapat diambil kesimpulan terhadap perancangan Sistem Pendukung Keputusan Penentuan Produk Kerajinan dengan Metode Weighted Product pada Dinas Perindustrian dan Perdagangan Kabupaten Tegal sebagai berikut:

A. Proses penentuan produk kerajinan dilakukan dengan 5 kriteria sebagai dasar penentuan, diantaranya Unit Kerja, Tenaga Kerja, Nilai Produksi, Nilai Investasi dan Nilai Kompetitif.

B. Hasil dari perhitungan penerapan metode dengan menggunakan data dari 3 alternatif yaitu S1,S2 DAN S3 menunjukan S2 dengan nilai Vektor $\mathrm{S}=$ 0.0370 dan Nilai Vektor $\mathrm{V}=0.3382$ Menjadi Ranking Tertinggi.

C. Penerapan Metode Weighted Product yang terimplementasi dalam sebuah sistem pendukung keputusan.

\section{Daftar Pustaka}

[1] E. P. Lestari, "Penguatan Ekonomi Industri Kecil dan Menengah Melalui Platform Klaster Industri," J. Organ.

Dan Manaj., vol. 6, no. 2, pp. 146-157, 2010.

[2] Peraturan Menteri Perindustrian Republik Indonesia, "Permenperin_No_64_2016.pdf."pp. 16, 2016.

[3] $R$. Fauzan, $Y$. Indrasary, and N. Muthia, "Sistem Pendukung Keputusan Penerimaan Beasiswa Bidik Misi di POLIBAN dengan Metode SAW Berbasis Web," J. Online Inform., vol. 2, no. 2, p. 79, 2018, doi: 10.15575/join.v2i2.101.

[4] M. Muslihudin and D. Rahayu, "SISTEM PENDUKUNG KEPUTUSAN SISWA BERPRESTASI MENGGUNAKAN METODE WEIGHTED PRODUCT | Muslihudin | Jurnal TAM (Technology Acceptance Model)," J. TAM (Technology Accept. Model., vol. 9, no. 2, pp. 114-119, 2018.

[5] Z. Alamsyah and D. Gustian, "Sistem Pendukung Keputusan Menggunakan
Metode Weighted Product Dan Simple Additive," Sist. Pendukung Keputusan Menggunakan Metod. Weight. Prod. Dan Simple Addit., vol. 3, no. 1, pp. 129-137, 2019.

[6] W. S. Dharmawan, D. Purwaningtias, and D. Risdiansyah, "Penerapan Metode $S D L C$ Waterfall Dalam Perancangan Sistem Informasi Administrasi Keuangan Berbasis Desktop," J. Khatulistiwa Inform., vol. 6, no. 2, pp. 159-167, 2018, doi: 10.31294/khatulistiwa.v6i2.160. 